\title{
BAPTYSTERIUM MEDIOLAŃSKIE
}

\author{
Baptysterium, w którym - jak squdziny - miaz miejsce
} 24 kwietnia 387 r. chrzost świętego Augustyna, stanowi część ecclesia episcopalis Mediolanu. Saqdzac z dotychczas odkopanych założé zespół katedry stallowł d, dobrze poświadczony na terenie północnej Italii oraz Galii, typ ecclesia geminata 1 składał sie z dwu bazylik, ustawionych jedna za druga i zaopatrzonych w baptysteria ${ }^{1}$. Wykopaliska, prowadzone pod dzisiejsza katedra i przod nia, odsłoniły dotychczas: oktogonalny basen starszej bazyliki /Vetus, Minor/, absydę i część murów basilica Nova/Maior, potem S.Thecla/ $i$ jej baptysterium zbudowane przez Ambrożego oraz salę dwuabsydowa /cella biabsidiata/, lezącą między południowym a zachodnim wejściem do baptysterium, budowani w takim samym murowanym watku jak liury baptysteriuin. 0 istnieniu divu kościołóv miejskich, określonych Jako Vetus/Minor/i Nova/Maior/mówi też wyraźnie św. Ambroży w liście do Marceliny z 386 roku².

Zespóz katedralny w Mediolanie powstawał stopniowo. Bazylika Vetus dotychczas nie odkopana, leżąca pod nawa główną dzisiejszej katedry, miała być zbudowana za vilroklesa, którego biskupstwo pokrywa się z rzadami Konstantyna Wielkiego ${ }^{3}$. Baptysterium tej bazyliki, leżace pod północną zakrystią Duomo znane

1 Wykopaliska prowadzono w latach 1961-1964 w zwiazku z budową stacji metra. Por. M. Mirabella Roberti, Il battistero antico di Milano, w: Atti del VI Congresso Internazionale di Archeologia Cristiana, Joma 1965, 703-707; to sano w artykule tegoz autora: Contributi della ricerca archeologica all' architettura anbrosiana milanese, w: "Studia Patristica ivediolanensia", VI, Milano 1976, 357-359; G. Bovini, Gli edifici di culto inilanesi d'eta preambrosiana, Corsi 1961, 50-56.

2 Epistola 20, 1, PL 16, 1036 B.

3 Przypuszcza się, że bazylika vetus lezała taril, gdzie od IX do XVw. stał, wymieniany w źródłach, kościół określany jako "ecclesia hiemalis S. Mariue". Dedykacje "hiemal is" ma też szereg imnycí kościoiów z grup kościołów podwójnych. Por. A. Capltand d'Arzagro, La chiesa Maggiore di Milano, Milano $1952,46-56$. 
Jest ze źródeł średniowlecznych jako przeznaczone dla chrztu kobiet ${ }^{4}$ - Bazylika Nova - sądząc z korespondencji Ambrożego ${ }^{5}$ funkcjonowała już w 355 r., kiedy to w czasie synodu ariańskiego został z niej porwany przez arian biskup Dionizy, który następnie wraz z towarzyszawi został wygnany z miasta ${ }^{6}$. Baptysterium tej bazyliki, w któryn umiejscawia się chrzest św. Augustyna, budował biskup Ambroży w latach 375-386.

Baptysterium ma kształt oktogonu o roẓiętości 19,30 m. W grubości muru, wynoszącej 3 metry, mieszczą sie cztery nisze prostokatne - zainstalowane zgodnie ze stronami świata, zaopatrzone w wejścia - oraz cztery ślepe nisze półkoliste. Te ostatnie pełniły prawdopodobnie role vestiarium, whórym na stojących w zakolu muru ławkach składano szaty przed wejścien do basenu. Pośrodku znajduje się oktogonalny basen, którego średnica ma od zewnatrz $6,10 \mathrm{~m}$, a od wewnątrz $5,16 \mathrm{~m}$., o głebokości $0,80 \mathrm{~m}$. Wischodni odcinek wewnętrznej ściany basenu ma charakterystyczne wcıęcie, które znajduje wytłumaczenie przy omawianiu przeblegu ceremonil chrzcielnej. Dobrze potwierdzona jest w Mediolanie całość Instalacji doprowadzających wode biezaca do basenu /zachował się kanał ceglany na rury i dojścia wykonane $z$ marmuru 1 brazu/ oraz rura odpływowa zachowana pod południowyra wejściem.

Wnętrze baptysterium było bogato zdobione. Na dolnych partiach ścian zachowały się ślady marmurowych okładzin. Posadzka wyłożona była czarnymi i białymi płytkaini kamiennymi o kształcie rombów, wieloboków i kwadratów. Wnętrze basenu

4 J. G. Picard, Ce que les textes nous apprennent sur les equippement et le mobilier liturgique neccesaire pour le baptêne, XI Congrès International d'Archéologie Chrétienne, Lyon 1986 /Pretirages des rapports s. 6/. 0 baptysterium określanym w źródłach S. Stefano ad fontes mówi tez 149 poenat Ennodiusza z pocz. VI wieku. Por. CSkL 6, 607, lub MGH Auctores antiquissini VII 8. 271, nr 379.

5 Epistola 63, 68, PL 16, 1259.

6 Biskup Dionizy jest uważany za budowniczego basilica Maior. Jego greckim pochodzenien tłumaczy sie niezwykły na zachodzie kształt transejtu toj bazyliki. Por. G. Traversi, Architettura paleocristiana inilanese, Milano 1964, 47-61. 
1 Jego stopnie wyłożone były płytaml greckiego marmuru. Pięknych efektów światłocieniowych dostarczały odsuniete od ścian kolumny, na których częściowo opierało sie nie zachowanesklepienie, kryte prawdopodobnie barwna mozaika, której część kostek odnaleziono. Pomysi zastosowania oktogonu w budowli chrzcielnej Ambrozy przejął najprawdopodobniej z cesarskich grobowców rzymskich widzac wym kształcie - jak mozna sądzić z przypisywanej mu inskrypcji - obok grobu "starego człowieka" symbol zmartwychwstania do zycia nowego ${ }^{7}$. Inskrypcja, składająca sie z 8 dystychów miała zdobić mury baptysterium. W jej treści, przechowanejw syllodze z Lorch, czytany, ze ósmy dzień bedzie dniem zmartwychwstania ${ }^{8}$.

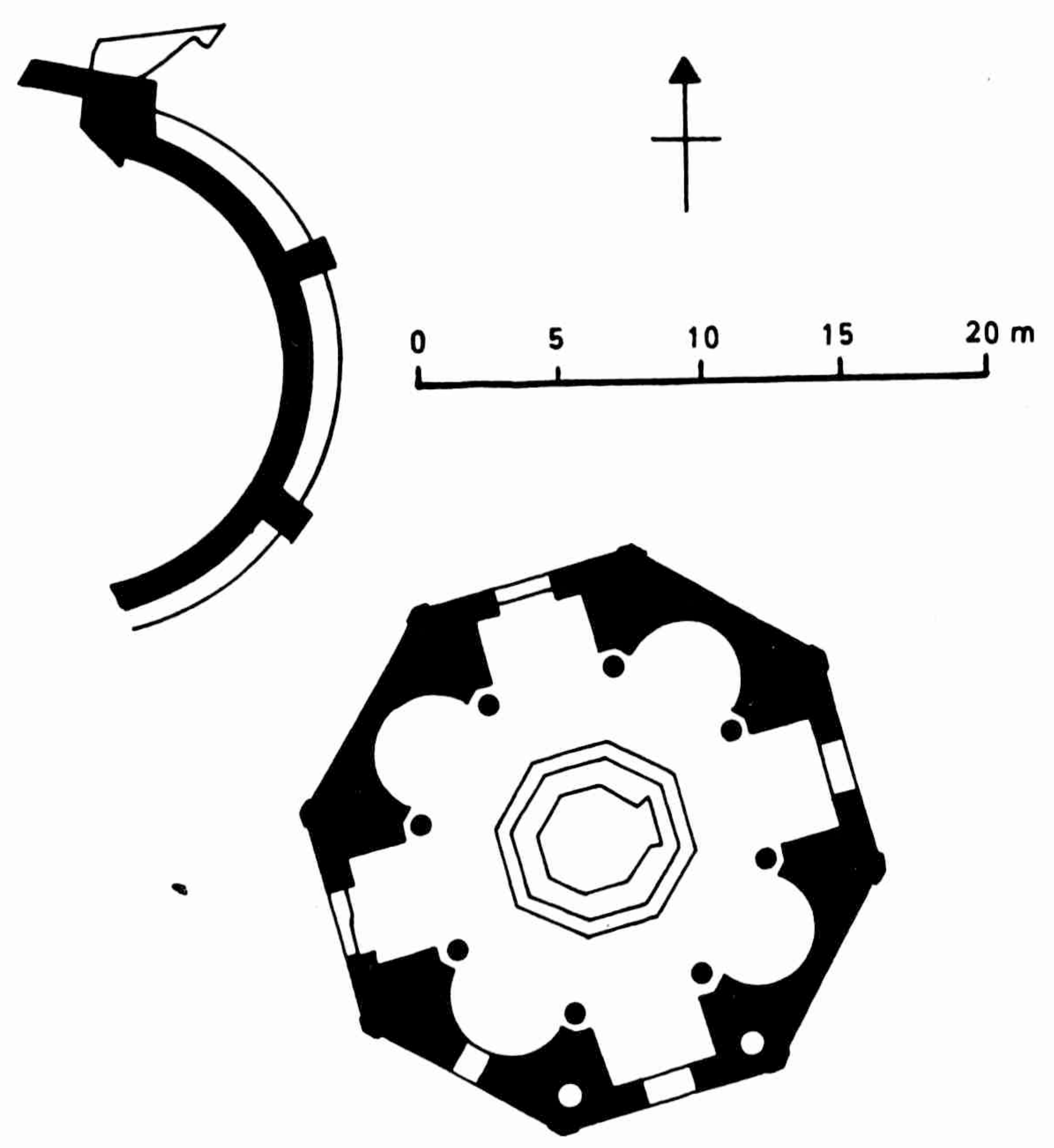

Uproszczony plan baptysterlum bazyl1ki / Nova, Malor, św. Tekl1/ oraz zarys absydy tej bazyliki.

7 Taki kształt ma m.il. mauzoleum Dioklecjaná w Spalato, a na terenie Mediolanu: mauzoleum poguriskie przy $S$. Vittore oraz mauzoleum teouozjańskie zw. potem S. Aquilino.

8 Codex Vaticanus Palatinus 833. Por. O. Perler, L'inscription du baptistêre de sainte'liècle a Milan et "De Sucramentis" de saint Ambro1se, RivAC 27/1951/ 145-166. 
Ryt chrzcielny, w głównych zarysach, daje się odtworzyć po pierwsze na podstawie przesłanek dostarczonych przez wykopaliska, a po drugie z informacji zawartych w dwóch traktatach św. Ambrozego: "De mystericis" 1 "De sacramentis".

Katechumen przed wejściem do baptysterium nazwanego "przybytkiem odrodzenia" 9 podlegal ceremonii otwarcia ust oraz wyrzekał się diabła. Wejócie następowało, jak można sądzić z tekstu Ambrożego, od strony zachodniej: "Wszedłszy więc, aby ujrzeć swego wroga, którego zamierzasz się wyprzeć w oczy, kierujesz sie ku wschodowi, bo kto wyrzeka sie diabła, zwraca sie do Chrystusa i patrzy prosto na Niego"10. Wejście zachodnie położone jest najbliżej cella biabsidiata, gdzie poprzednia ceremonia mogła mieć miejsce.

Dalej pisze Ambroży: "Co ujrzałeś? Wodę. Owszem, lecz nie tylko. Lobaczyłeś jeszcze usługuj ¿̨cych tain lewitów i biskupa, który zadawał pytania $i$ poświęcał"11. Jest tu niewatpliwie mowa o poświeceniu wody. Ambroży przypomina cud wara $i$ dalej pisze: "Dopóki bowiem nie odda się czci Krzyzowi Parskiemu, woda Jest zupełnie nieuzyteczna dla przyszłego zoawienia /... Podobnie jak Mojżesz, jako prorok, włożył laskę do tamtego źródła, tak do tego źródła /tzn. basenu/ kapłan wkłada pochwałe Krzyża Pańskiego, a woda nabiera słodyczy łask"12. Fragment z dzieła "De Sacramentis" pozwala nain poznać, co mówil biskup przy ceremonil poświęcenia wody: "Kapłan dokonuje nad wodą egzorcyzmów, następnie zanosi błagania i modły o uświ ęcenie źródła chrzcielnego 1 o obecność wieczystej Trójcy"13.

Po wejściu katechumena do baptysterium miało miejsce namaszczenie prawdopodobnie całego ciała, poniewaź jest porównane przez Ambrozego do namaszczenia ciata zawodnika przed walka ${ }^{14}$. Dok onywał go kapłan i diakon.

"Nastepnie podszedłeś bliżej, zobaczyłes źródło chrzcielne 1 stojucego nad nim biskupa"15. Biskup stat najprawdopodobniej

9 De mysteriis 5, PL 16, 407: "regenerationis sacrarium". 10 De mysteriis 7 , PL 16,408, tłlum. L. Gładyszewsk 1, POK 26, 37. 11 De mysteriis 8, PL 16,408, POK 26, 37.

12 De mysteris 14, PL 16, 410, POK 26, 38.

13 De sacramentis $\mathcal{I} 18$, PL 16, 441, tłum. L. Gładyszewsk1, POK 26,58 .

14 Por. De sacramentis I 4, PL 16, 437, POK 26, 54.

15 De sacranentis I 9, PL 16,438, POK $26,56$. 
w iniejscu wcięcia ścianki basenu po stronie wschodniej. To było wiejsce, do którego raial przejsc przez wodę katechumen. Przestrzen ta wynosi ok. 5 metrów, co unaocznia porównanie do przejścia przez dorze Czerwone ${ }^{16}$. "rodszedłeś do sadzawki chrzcielnej, wszedłeó do niej, zobaczyłeś biskupa,obok dostrzegłeś ’ewitóm 1 kapłana"17. Z tego opisu można sądzić, że ceremonii zanurzania dokonywał kajłan i diakoni, którzy razem z katechumenem stali wodzie/głębokosc basenu wynosi $80 \mathrm{~cm} /$. Nad nimi, wyżj, stał biskup, który nie wchodził do wody. Ambroży nie podaje, jak zanurzano katechumena: mógł kucać, wógł też kłaść się na podłodze basenu, w czym llusieliby mu pomagać diakoni. Ich obecnośc w basenie zdaje się przemawiac za ta drugį wersju. Ona téz lepiej odpowiada Pawłowemu porównaniu cinrztu do śmierci /Rz 6, 3-4/, do którego nawi azuje Ambroży" 18 . Tekście "De Sacramentis" Ambroży pisze: "Zapytano cię: 'Czy wierzysz w Boga Ojca wszechmogacego'. Powiedziałeś: 'Wierzę 1 zanurzyłeś się, to znaczy pogrzebano cie $/ \ldots /^{19}$

"Potew /tzn. po wyznaniu wiary i trzykrotnym zanurzeniu/ podszodłes do biskupa. Rozważ, co dalej nastąpiło?"20 /... Katechumen otrzymywał "na głowę" namaszczenie. Dlatego na głowę, bo "mádrość bez taski więunie, ale otrzynawszy ja zaczyna działać w sposób doskonały"21.

Po wyjściu z basenu nowo ochrzczonemu czytano opis umycia nóg /J 13/22, a potem otrzymywał on biały strój ${ }^{23}$. W "Le sacramentis" Ambroży opisuje ponadto obrzed umycia nóg nowo ochrzczogo przez biskupa, przyznając, że Kościół rzymski, "którego przykład i wzór we wszystkim naślauujemy" nie stosuje tego obrzędu. Tłumaczy to następująco: "Może zaniechał go dlatego, że często odbywa sie tam ceremonia chrztu" ${ }^{24}$. W Mediolanie chrzczono tylkow Wielka Sobotę, a w lzymie kilka razy do roku.

16 Por. Le sacramentis I 12, PL 16, 439, POK 26, 50.

17 De sacramentis II 16,447 , POK $26,63$.

18 Por. De sacramentis II 23 i III 1, PL 16, 449, POK 26, 65-66.

19 De sacramentis II 20 , PL 16, 448, POK 26, 64.

20 De mysteris 29 , PL 16,415 , POK 26, 42.

21 De sacramentis III 1, PL 16, 449, POK 26, 66.

22 De mysteriis 31 , PL 16, 416, POK 26, 42 .

23 De mysteriis 34 , PL 16,417 , POK $26,43$.

24 De sacramentis III 4-5, PL 16, 451-452, POK 26, 67-68. 
Nastejna ceremonia miała juz miejsce poza baptysterium. Ambroży nie mówi wyraźnie, gdzie udzielano sakramentu bierzmowania, który określa jako "spiritale signaculum"25, ale sagdząc z tego, że bezpośrednio po tym obrzędzie mówi: "możesz podejóć do ołtarza" 26 , miało to prawdopodobnie miejsce wościele.

$\mathrm{Z}$ baptysterium wychodzono prawdopodobnie północnym wyjściem, przed któryin zachowały się schody. Jest to wejście położone najbliżej bazyliki waior/S. Thecla/ lub tez - co byłoby bardziej zgodne z zasadami chrzcielnymi - wejściem wschodnila prowadzácym do bazyliki Vetus/S. Mariae/.

\section{Barbara Filarska - Lublin}

\section{THE BAPTISTERY OF MILAN /Summary/}

The report brieily describes the baptistery where St. Augustine's baptism probably took place. It outlines a probable rite of this ceremony. 